\title{
Late Night Thoughts on Blogging While Reading Duncan Kennedy's Legal Education and the Reproduction of Hierarchy in an Arkansas Motel Room
}

Franklin G. Snyder

Texas A\&M University School of Law, fsnyder@law.tamu.edu

Follow this and additional works at: https://scholarship.law.tamu.edu/facscholar

Part of the Law Commons

\section{Recommended Citation}

Franklin G. Snyder, Late Night Thoughts on Blogging While Reading Duncan Kennedy's Legal Education and the Reproduction of Hierarchy in an Arkansas Motel Room, 11 NEXUS 111 (2006).

Available at: https://scholarship.law.tamu.edu/facscholar/185

This Article is brought to you for free and open access by Texas A\&M Law Scholarship. It has been accepted for inclusion in Faculty Scholarship by an authorized administrator of Texas A\&M Law Scholarship. For more information, please contact aretteen@law.tamu.edu. 


\title{
Late Night Thoughts on Blogging While Reading Duncan Kennedy's Legal Education and the Reproduction of Hierarchy in an Arkansas Motel Room
}

\author{
Franklin G. Snyder*
}

Blogging is a curious activity. It is solitary, in the sense that most blogging occurs when one is alone, but blogging is also communal in the sense that the very act involves participating in a larger dialogue. Sometimes I think it is like the work of a monk of the Middle Ages, alone in his cell with a candle laboriously copying the books that will take their place in the international dialogues of the day. At other times, I think blogging is more like spray-painting graffiti at night on top of the graffiti painted by those who went before you.

My own blogging tends to be done early in the morning or late in the evening, and as this piece has to do with blogging, I thought I would write it while I am doing my blogging. It is being written in bits and pieces; some at the small student desk in my neat and pleasant little apartment at Notre Dame, where I am visiting for the year; some in the den of my less neat house in College Station, Texas, where my wife and two sons (ages

* Visiting Professor of Law, Notre Dame Law School, 2005-06; Professor of Law, Texas Wesleyan University School of Law in Fort Worth. Thanks to Rachel Arnow-Richman, Ann Mirabito, and Jeff Lipshaw for comments on the manuscript. The views expressed here are not necessarily shared by any of them, especially Rachel, who very much enjoyed the contracts course she took from Duncan Kennedy. I am also grateful for the hard work of Beth Gaschen and the editors of this journal for their work in fixing (and adding) a number of footnotes. 
5 and 6) live, and to which I commute back on weekends. Some is written at various places in between, mostly airports, but also (at this moment) the Days Inn in Lonoke, Arkansas, which happens to be ten hours from South Bend and eight from College Station.

According to its Chamber of Commerce web site, Lonoke (pop. 4,287) has 33 churches: 14 Baptist, 5 Methodist, 2 Church of Christ, 1 Presbyterian, 1 Assembly of God, and 9 assorted non-denominational Protestant outfits, and a Mormon temple. ${ }^{1}$ The biggest employer in Lonoke is the Remington ammunition plant. ${ }^{2}$ The second-biggest employer is Wal-Mart. ${ }^{3}$ It is hard to imagine a place further removed from the elite groves of academia.

Yet here I am, 11:00 o'clock at night, sitting at a faux-veneer pressboard table in front of a Hewlett Packard laptop in a little room that looks out across the parking lot at the I-40 overpass, enjoying free high-speed wireless Internet service that puts me instantly in touch with as many resources as any good law library can muster. Lexis, Westlaw, Hein Online, the Questia library of books, the Social Science Research Network, Google, Fox Sports-all the information a human being could reasonably want, and a good deal more, is only seconds away. That laptop is a potent symbol both of modern technology and the democratization of information.

Next to the computer on the little table is a book. Yes, a printed book. It is the handsome recent New York University Press reissue of Duncan Kennedy's 1983 Legal Education and the Reproduc- tion of Hierarchy: A Polemic Against the System (LERH). ${ }^{4}$ It is not only a printed book, it is the ultimate elite artifact, a book by the Carter Professor of General Jurisprudence at Harvard Law School, suitably ensconced between the sober boards and gold lettering of one of America's premier academic presses. It is a potent symbol of elite control of the academic discourse. Everything about it reeks of status. The book blurbs on the dust jacket are from the Bennett Boskey Professor of Law at Harvard, ${ }^{5}$ the Carmack Waterhouse Professor of Constitutional Law at Georgetown, ${ }^{6}$ and (hoping for some bookstore sales, maybe) bestselling author Scott Turow, probably the only guy who has ever made law school sound as scary as Kennedy.? The new edition contains four new essays about the original work; all from what the dust jacket reminds us (quite correctly) are "prominent legal scholars." ${ }^{\text {T }}$ The review of the book on Amazon.com emphasizes that the work is important enough that it "was reviewed in several major law journals." Translation: this book has been taken very seriously by people who know about that sort of thing. Kennedy's $L E R H$ is quintessentially a product of the academic hierarchy. It is, as I discuss further below, written by an elite insider for other insiders, on a subject that is likely to interest only insiders or insider wannabes.

The Internet, and that particular part of it that has come to be known as the blogosphere, is the opposite. It is a product of what may be the most democratizing technological advance since the development of cheap wood-pulp paper. 


\section{Franklin G. Snyder}

Only the best and brightest can get their words into a NYU Press book. Its mere existence tells you that it is important. Any bumpkin with $\$ 49.50$ and a modem can have a blog.

The insider book rails against the power of hierarchies and their exclusion of outsiders. On the Internet, outsiders, without muss and fuss, are busy undermining those hierarchies.

$* * *$

There are two broad hierarchies in American legal education. First, there is the hierarchy of law schools in which each institution has its allotted spot in the pecking order. Second, there is the hierarchy within law schools. All the various folks on the faculty, who do much the same thing, have a wide array of job statuses, from Distinguished University Professor (or its equivalent) down to humble Legal Writing Instructor. There are a few anomalies, but if you know a faculty member's school and title, you can pretty much tell where he or she fits in the great academic pecking order.

Kennedy's $L E R H$ is the most famous exploration of these hierarchies. There is more to the book, of course, but for present purposes its theses are: (a) hierarchies are bad; (b) the hierarchy of the legal profession is especially bad; and (c) law schools contribute to the hierarchy of the legal profession and thus are also bad, not to mention miserable places to be. I do not think it is necessary to go into more detail here. There are many interesting things in the book and some acute observations, and many have found it "insightful," "stunning," and "vital, incisive, and daring."10 Others, of course, have found it "sophomoric agitprop."1 But for present purposes, we can skip the details and focus on the basics.

Our perceptions of the world, as everyone seems to agree, are shaped to some degree by our own backgrounds. Kennedy has apparently spent his life since age ten competing in "deadly earnest" in the cutthroat world of elite academia. ${ }^{12}$ He went to Cambridge's famous Shady Hill School, to Andover, to Harvard, and to Yale Law School-all of them, it seems, pretty dreadful places-before going back to Harvard, where he has taught since the Nixon Administration. ${ }^{13}$ LERH is the ultimate alienated-insider take on an institution where the author has spent his entire adult life.

As it happens, LERH came out the same year I graduated from law school. I was unaware of it until I entered legal academia in 1997. This is perhaps just as well, since it might have led me to conclude that my law practice was dull and soul-killing work, when in reality I found it challenging and enjoyable. Nor did I read it during my early years in academia. When one is brutally clawing one's way up a soul-killing hierarchy, busily sacrificing everything that is best about oneself in the process, it is probably counterproductive to be told that it will all be dust and ashes when one gets there. If I had realized just how much of my humanity I would have to surrender to reach my own modest niche in the hierarchy, I might not have tried. Which would be too bad, since I enjoy it very much. 


\section{NEXUS}

Before I entered academia, I clerked for a judge on the D.C. Circuit, was an associate and partner in the D.C. office of Latham \& Watkins, then spent four years doing mom \& pop law as counsel to a small firm in Oswego, New York. Since joining the academic ranks, I have taught at law schools in all four U.S. News tiers. ${ }^{14}$ I've also filled most of the various slots between "legal writing teaching fellow" and "tenured professor of law." For the past year or so, I have been a blogger, as the chief editor of ContractsProf $B \log ,{ }^{15}$ the "official" blog of the Section on Contracts of the Association of American Law Schools (AALS), and more recently as webmaster of its website. I have been active in the section and have put on a few conferences that have drawn together a wide range of scholars at all levels. ${ }^{16}$

I mention this because it affects the perspective I bring to Kennedy's book. I have few advantages over Kennedy as an observer of legal and academic hierarchies, but the one I have is breadth of experience.

$$
* * *
$$

So, I pick up $L E R H$. It starts off well. What law schools teach is not just "wrong, or nonsense," but "nonsense with a tilt."18 It is ideological training for willing service in the hierarchies of the corporate welfare state, ${ }^{19}$ in a classroom that "suggests at once the patriarchal family and a Kafka-like riddle state.""o All this is a little overblown, of course, but most of us remember some of the things we liked least about law schools, even those who, like me, enjoyed their ex- perience. I settle down for a good, oldfashioned searing indictment.

After fifty or sixty pages the sledding gets tougher. Toward the end it even becomes something of a chore to finish. It is not so much that I disagree with some of Kennedy's points (though I do), or that the writing is not engaging (it is). No, what starts to wear me down is the apparent conviction that his own experiences and feelings are true and universal, and that mine, to the extent they differ from his, are either the result of bad faith or denial. Perhaps Kennedy really was emotionally maimed by his own "fear of the teacher's disapproval," his "own status as a non-person" in the classroom, or his "revulsion" at the Socratic method. ${ }^{21}$ If so, I suspect this has more to do with Kennedy and his parents than it does with legal education. But that does not stop him from casting it as some kind of universal reaction, at least among thinking people.

For a while, it is kind of amusing being told that I am probably part of the class that cannot relate to "working class people" or "outsiders" by a guy who has the same privileged class status and education as George W. Bush. ${ }^{22}$ Or learning that, as someone who liked law school, liked law practice, and likes teaching, I must be one of the "mainstream" people for whom "the barrio . . . is alien and invisible." ${ }^{23}$ I mean, I grew up across the street from the Carmelas barrio in Norwalk, California, and a third of my high school classmates came from there. ${ }^{24}$ Just whom are we talking about here?

If the reader's own background happens to parallel Kennedy's, perhaps he or 


\section{Franklin G. Snyder}

she can recognize the traumas he had to go through (like having his day ruined because a professor was in a bad mood) and think them both important and universal. But if the reader's background was more, well, outsiderish, it is probably harder to relate. Kennedy was already a Harvard professor writing about how much he had to suffer in law school ${ }^{25}$ back when I was pulling the night shift at a liquor store-convenience mart in Long Beach, California (working alongside a guy who belonged to the Chosen Few motorcycle gang), to pay my way through Cal State Fullerton. He was making a Harvard professor's salary when I was living next to a family of immigrants in one unheated room in a converted Quonset hut, adjacent to the largest asphalt refinery in California. ${ }^{26}$ Frankly, whether my professor was having a bad day or not, it did not make much of a difference in my life. When you have found yourself lying face-down on the floor, feeling a gun at the back of your head while a very agitated man keeps screaming "Open the safe, motherfucker!"27 the "deadly earnest" competition of Shady Hill School, Andover, Harvard, and Yale does not seem quite so central to the fate of society.

$$
\text { *** }
$$

Still, the man has a point. There is a great deal of hierarchy in legal education and some of it is probably not merely unnecessary but pernicious. Unlike Kennedy, I am not one of those for whom all hierarchy is, at best, a necessary evil, and who distrusts even the division of labor. I have children who need to listen to me when I tell them to look both ways. I have students who need to do what I tell them if they want to learn what I have to teach them and not screw up the lives of the people they will represent when they graduate. I would prefer to be operated on by board-certified surgeons rather than the people who work in the hospital cafeteria. Like Paul Carrington, one of the legal scholars who has a brief essay in the NYU edition of $L E R H$, I lack Kennedy's imagination-I simply cannot envision a world without hierarchies. ${ }^{28}$ So, I cannot regard them as inherently evil, especially since, as one who teaches contracts and business associations, I am aware that they can be liberating. The hierarchical structure of a business enterprise or a nonprofit corporation allows people to accomplish together what they simply could not accomplish as an aggregation of individuals.

On the other hand, they can be cruel and stultifying. I am perfectly willing to agree that the hierarchies in legal academia are more pointless and rigid than they need to be. The hierarchies of, and within, law schools are far less fluid, flexible, and inclusive than those of even the elite bar. Some of the leading elite firms today were, after all, jumped-up regional outfits with big ideas when Kennedy was writing $L E R H$, and some of the old-line elites (Lord, Day \& Lord, Coudert Brothers) have gone the way of the carrier pigeon. Today, the elite law firms have partners from virtually every American law school, even the ones down at the bottom that you have never heard of. I suspect there are more lawyers with 
J.D.s from fourth-tier schools at one elite firm, Skadden Arps, than there are in all of legal academia combined. There is certainly no lawyer in any elite law firm who is treated as comparatively poorly as a legal research and writing teacher at most American law schools.

So let us assume we want to rattle the law school hierarchy. Let us assume that the world is teeming with outsiders who want to shake things up in the academy. Kennedy's tract has been around for more than two decades. Most of the editors of this NEXUS issue were probably still spitting up creamed broccoli on their bibs when it came out. Yet it is hard to see that law schools have become less obsessed with status over those decades. Two of the other scholars who contribute to the NYU edition, Angela Harris and Donna Maeda, note how "fresh" Kennedy's "polemic against the system" still is. ${ }^{29}$ This is, I think, a nice way of saying that it has had very little effect on anything.

Why? Partly, I expect, because after all the wind-up, the book's delivery is weak. A student reading $L E R H$ may start looking for a call to man the barricades, to take some concrete stops, but all Kennedy winds up telling students is "Resist!" Without some details, this is not terribly helpful. After all, the students who are most likely to be irritated by the modern elite law school, and most likely to speak up about it in class, are probably those that Kennedy calls "cocky conservative women" ${ }^{31}$ and "right-wing econ jocks, ${ }^{32}$ whom he would just as soon see shut up, ${ }^{33}$ and who probably like hierarchies, anyway. They are almost cer- tainly in Kennedy's classroom because Harvard is the most prestigious law school in the world. ${ }^{34}$ Even the left-wing students-more intelligent, sensitive, and better educated (they have read more Foucault than Coase)-are probably there because Harvard is the most prestigious law school in the world. After all, if they really wanted public service more than prestige they could have gone to, say, Northeastern, Texas Southern, the City University of New York, Howard, the University of the District of Columbia, the New College of California, or any number of other places with a strong historic commitment to social justice over elitism.

$$
\text { *** }
$$

There is another factor at work, though. Despite Kennedy's rhetoric about how outsiders are "invisible" to mainstreamers, the fact seems to be that nearly everything outside of Harvard is invisible to Kennedy. In the years since 1983, there has been a near-total revolution in access to information and to media for expressing viewpoints. Yet, for all I can tell from the new edition of $L E R H$, it is still 1983. The world is still dominated by the corporate welfare state. If it is not on the network evening news, in the New York Times, or in the Harvard Law Review, it does not exist. The only way for like-minded individuals to resist the overwhelming forces of hierarchy is to found little Marx study groups inside the elite law schools. ${ }^{35}$

Kennedy's focus is relentlessly on what is going on inside the elite law 


\section{Franklin G. Snyder}

schools. Utterly absent from $L E R H$ is the notion that the hierarchy might be changed by something outside itself. Kennedy casts this narrow focus in a positive light by saying that he is calling for "interstitial" revolution, within the institution, not from above or below. However, he does not explain why an interstitial revolution is better than revolution from above or below. Perhaps it is because he feels interstitial revolutions are somehow more democratic than revolutions from below? It is hard to say. A cynic might note that the chief advantage of an interstitial revolution is that the current cast of characters gets to keep their jobs.

But that would be uncharitable and probably untrue. I suspect the real reason for Kennedy's myopia is that those who have invested their entire lives in an institution naturally assume that what goes on inside that institution is vitally important. One can see this in the legal and business worlds from time to time. People inside organizations seem to want to believe that what are actually secular changes in supply or demand are somehow due to their own good or bad acts. It is harder to avoid this tendency when you have relatively little experience outside your own organization. Many legal academics have little with which to compare their experiences:

The typical ... scholar attended an Ivy League (or comparably selective) college in the 1960 s or early 1970 s, went on to study at an elite law school, perhaps spent a year clerking for a prestigious judge, and then proceeded directly to a position on the faculty of a top-tier law school. It must be difficult indeed, in such a hothouse career, not to think that all the conditions of one's work have real-world import-not to think that one's professional frustrations reflect an oppressive hierarchy, that one's personal satisfactions represent a universal ideal, that every administrative decision at one's institution is a matter of genuine political moment. ${ }^{36}$

It is natural in such circumstances, as one sympathetic commentator wryly noted, for something like the "issue of the "no hassle pass" to become "the issue upon which the fate of capitalism depended." 37

$$
* * *
$$

The NYU edition of $L E R H$ contains a facsimile of the first 1983 edition, so the reader can see it the way Kennedy wanted it to look. The original booklength version of the work was self-published by Kennedy on paper specifically cut into an odd shape, set in a quasi-Courier typeface designed deliberately to look like an IBM DisplayWriter, photocopied and stapled with an amateurish cover design.

Why? After all, by 1983 Kennedy had been a tenured faculty member at Harvard Law School for seven years, and his influential Critical Legal Studies (CLS)-oriented work had already appeared in journals such as the Harvard Law Review, the Stanford Law Review, the Yale Law Journal, and the University of Pennsylvania Law Review. Portions of $L E R H$ first saw the light of day as an essay in a book published by a reasonably prestigious commercial press. ${ }^{38}$ That book sold well enough that it has gone through three editions and is still in print. Kennedy also published a some- 
what different version in that bastion of the Establishment, the Journal of Legal Education (JLE), ${ }^{39}$ the official peer-reviewed organ of the official "learned society" of legal education, the Association of American Law Schools (AALS). Since $J L E$ is, I believe, the only law review automatically distributed personally to every law professor in the country, every law professor in the country already had a copy of Kennedy's ideas on his or her desk, accompanied by the official imprimatur of the AALS.

However, as Kennedy writes in a new Afterword in the NYU edition, he wanted to publish a longer version. ${ }^{40}$ There is not the slightest doubt he could have published it in a law review, probably an elite one. He probably could have published it as a book, since he has had no difficulty getting his later books published by the perfectly respectable Harvard University Press. ${ }^{41}$ Instead, he decided to publish it himself. He did not do it as a capitalist might, to make money. He did it in what seems to have been a deliberate decision to make his ideas appear marginal and to limit their circulation.

The form of self-publication was extremely important to him. The ordinary outsider, eager to have the work taken seriously by insiders, normally opts to produce the most professional-looking thing he or she can afford. But Kennedy did not want the professional look:

I was reading lots of books about revolutionary movements at the time, trying to figure out how they worked before they became oppressive governments, and so was exposed to pamphlet literature as an idea. Through an Office of Information Technology, Harvard Law School was for the first time making word processing available to its faculty. I was influenced by the cult of the handmade artifact, in which I was indoctrinated at Shady Hill School in Cambridge during the $1950 \mathrm{~s}$, and by the ideology of the pamphlet itself, my own ideology of the time, affirming the desirability and possibility of the 'revolution of civil society' carried out without official media, 'interstitially' rather than from above or below the institutions where we work. ${ }^{42}$

Look at the paradox. Here we have the ultimate insider, using the resources of the richest and most influential university in the world, publishing ideas that have already seen the light of day in a commercial book and a peer-reviewed law journal, and would be eagerly accepted by a hundred other respectable publications. Yet, he is working hard to make it look like the clandestine works of some hunted Spanish anarchist who is just one step ahead of Franco's secret police.

Janet Halley, another of the scholars who has an essay in the NYU edition, compares reading Kennedy's original tract to her experience reading the ephemeral radical tracts of rebel Puritans in 17th century England.43 Ultimately, there is not much comparison between the two. The Puritans were outlaws who had to move their presses every night to avoid being captured by the government licensing authorities. They published hurriedly and ungrammatically on cheap paper because they did not have time for editing or access to better paper.

I expect that the same is true for Russian Bolsheviks, the samizdat publishers in the former Soviet Union, and other marginalized groups. These groups, like all outsiders, do not publish crude pam- 


\section{Franklin G. Snyder}

phlets because they like publishing crude pamphlets. They publish them because they lack access to more established organs of communication. The pamphlet is not an ideology; it is a technology. It is the one you use when you cannot get your words out in any other way. But for Kennedy, the form of the pamphlet was to be extremely important. He did not want it to look typed (which would be too outsider) or printed (too insider) so he settled on something in between, the look of an IBM DisplayWriter. Here is his thinking:

The pamphlet tells us that it is an artifact because it is much more in print than a typed manuscript, while definitely not appearing to have been commercially produced. $L E R H$ was accordingly square, $7^{\prime \prime} \times 7^{\prime \prime}$, so that it could be made of $8^{1 / 2} 2^{\prime \prime}$ 14" (legal size) sheets folded in half and then cropped . . . . A square bound back would have cost a lot more and suggested publication, sale on bookstore shelves, and placement in libraries, rather than distribution on the street ....

The front and back covers are handlettered, using Letraset stick-on letters and graph paper, with minimal adjustment of letter size to space . . . . The cover looks a little like the layout of pre-World War I French socialist poster art and a little like Mao's 'Little Red Book,' in the mode of self-mockery. The Broadway typeface contradicts the Commie red. My name in Times New Roman is a reassuring gesture. AFAR [the name listed as publisher] might mean that the author is coming from a place that is a long way from 'the mainstream' . . . and it might be a reference to Lenin's 'Letters from Afar,' written in Switzerland before the Germans sent him back to St. Petersburg .... But another possibility is an acronym like those of the guerilla groups that multiplied in Latin America in the sixties and seventies (e.g., the FARC): perhaps 'Armed Forces of Anarchist Revolution,' or more consistent with the text, 'American Front for Anarchist Resistance."44
There are several oddities here. Why is one who is seriously calling for revolution mocking himself? Did anybody ever notice the difference between the Broadway and Times New Roman typefaces? Most curiously, to get that published-on-scrappaper look, Kennedy had to take normal paper and crop it down to the offbeat size, throwing the remainder away. Try to imagine Janet Halley's rebel Puritans wasting paper.

To cap things off, despite the rhetoric, the final book was not even actually distributed "on the street." The only place you could buy it was off the shelves of that haven of oppressed outsiders, the Harvard Bookstore in Cambridge.

$$
\text { *** }
$$

Okay, it is easy to make fun of this. Watching Kennedy do "outsider" is like watching Marie-Antoinette do "milkmaid." I sense the good will, but down deep I know that Kennedy is not going to have to hide from the police in some Paris sewer, any more than the Queen, after a day of playing with the cows, is going to spend the night in a bug-infested hay rick. It is like the portrait photo of Kennedy that Harvard published on his 1996 investiture as Carter Professor of General Jurisprudence: $t$-shirt, leather jacket, and shades ${ }^{45}$-just like my old biker comrade from the Stop-N-Go in Long Beach.

Nothing about $L E R H$ suggests that Kennedy is interested in real dialogue with real outsiders, that is, from outside the Harvard walls. Curious, I visit his website. $^{46}$ Yes, despite my comments 


\section{NEXUS}

about the way Kennedy seems to have ignored technology, he has one. The entrance portal, in stark black and white, shows a gargoyle face with "enter" in its mouth, and, in large letters, merely the legend:

\section{Duncan Kennedy \\ Carter Professor of General Jurisprudence Harvard Law School ${ }^{4}$}

Clicking on "enter" in the gargoyle's mouth, brings up the home page, where the lettering is designed to look like a typewriter, the old fashioned manual kind where the letters are uneven and clogged with ink, like the Woodstock that Alger Hiss or some federal agent might have used to type the Pumpkin Papers.

What is on the site? Kennedy. All Kennedy, in fact, all the time. Visitors can read his short biography and there is a rather arty photo of a man taking a photo of Kennedy. ${ }^{48}$ The blurred back of the photographer's head dominates the foreground, with Kennedy in the background holding an umbrella. There is no explanation for the umbrella, since it does not seem to be raining. ${ }^{49}$ Presumably, the structure of the photo is designed to remind you that the photo is an artifact, not reality, in case you were confused. There is the page with his publications, which can be viewed either chronologically, to see the development of his ideas, or alphabetically. ${ }^{50}$ There are links to online texts of most of them, though not to the self-published $L E R H$, which readers presumably must buy. There is even a link on each page so that visitors can e-mail the page to someone whom they think will be interested.
But there is no link to Kennedy; no email address, no button to send him a message. This seems odd for someone who ostensibly wants to reach out to outsiders. Maybe visitors want to tell him how much they appreciate his work, how it changed their life. Maybe they have a question. Maybe they want to respond to one of his claims that they think is wrong. Maybe they just want to act out their rage at their own otherness and vent on one of the exploiting class.

Tough luck. They can't. A visitor to Kennedy's website can read what Kennedy has to say to them, but Kennedy has designed his website so that visitors cannot communicate with him. It is eerily like his description of the "traditional" law teacher. To use his own metaphor, one can either "sit at [his] feet" and be mentored by him, ${ }^{51}$ or leave. His website is like law school, only worse, for at law school at least a student can talk back to the teacher. ${ }^{52}$

This is, it seems to me, all of a piece with $L E R H$. He is inside, the ordinary reader is not. His mission is, in fact, not really related to outsiders. He is not interested in shaking up the world to help outsiders-or at least to get involved in doing so himself. He wants to shake up Harvard. Twenty years after $L E R H$, he is still looking inward:

It would be a good idea to find a way to hook up with one another and kick against the traces of the present-by analyzing and protesting inside law school, against law school . . . . Resistance is an attitude that turns into an activity, that becomes a habit, and pretty soon it's like the habit of exercise and you feel bored and un-used when you aren't making trouble for someone somehow. ${ }^{53}$ 


\section{Franklin G. Snyder}

Kennedy's primary interest is not building bridges with the outsider, but battling the Harvard administration.

$$
* * *
$$

Meanwhile, far from the Charles River, things are changing. Perhaps the most curious thing about the new edition of $L E R H$ is that with all the vast social and technological changes that have rocked the legal profession, Kennedy writes that he "had a better idea" in 1983 of how he might build "student-faculty coalitions" than he has today. ${ }^{54}$ When Kennedy wrote $L E R H$, the only online legal resources were Lexis and Westlaw, both of which were largely inaccessible to anyone outside a law school or a successful law firm. Today, vast amounts of legal materials are free on the Web for anyone. Websites collect and offer this information, giving those who provide legal services to ordinary people access to more legal resources than even an elite law firm could have mustered when Kennedy wrote.

The possibilities for organizing outsiders have, moreover, exploded. E-mail, websites, and listservs offer a powerful way to get information out instantaneously and cheaply. For example, the Society of American Law Teachers has come into being since Kennedy wrote $L E R H$. It is the largest independent group of American legal academics, and its goals are "creating and maintaining a community of progressive and caring law professors dedicated to making a difference through the power of law," and "challenging faculty and students to develop legal institutions with greater equality, justice and excellence." ${ }_{55}$ This is precisely the sort of thing that Kennedy seems to be calling for. SALT is a remarkable and egalitarian group whose leadership comes from every law school strata, and whose members are united chiefly by their shared commitment to progressive values. Meanwhile, on the other side of the spectrum, the Federalist Society has used technology to build a network of more than 25,000 lawyers, academics, and students committed to their very different vision of legal education. ${ }^{56}$

The ability of the institutions, particularly the elite ones, to control the dialogue of legal education has decreased dramatically. Even the information that previously circulated largely among faculty at elite institutions-drafts of working papers destined for the Yale Law Review, for example-are now posted on the Social Science Research Network (SSRN) where anyone can view them for free. ${ }^{57}$ The $114,700^{58}$ or so papers on SSRN allow even those without access to a good law library the chance to read and comment on the latest legal thinking. Furthermore, the absence of a peer-reviewer or a law-journal gatekeeper means that nearly everything is published, regardless of the author's identity. If it is interesting and well done, people will read it regardless of the status of the writer. Papers by unknowns routinely get more downloads than those regarded by peer-reviewers as top in their field. Downloads, of course, are not a measure of quality, but they are a testament to the ease with which relative outsiders can reach an audience. 


\section{NEXUS}

The Law Professor Blog Network, ${ }^{59}$ of which ContractsProf is a member, was not designed to change the world. Its goal was to provide resources to law teachers and, I suspect, to make a few bucks for the founders. It is determinedly apolitical, but its mere existence is breaking down barriers between law schools and within law schools. The bloggers on the network, at this particular moment, come from every tier of American law schools: Arizona, Ave Maria, California-Davis, Cincinnati, DePaul, George Washington, Georgia State, Hofstra, Louisiana State, Minnesota, Mississippi, Missouri-Kansas City, Nevada-Las Vegas, North Carolina, Northern Kentucky, Ohio State, Roger Williams, Southern Illinois, Southern Methodist, Temple, Texas, Texas Tech, Texas Wesleyan, Tulane, Wayne State, Widener, Willamette, and William Mitchell.

Not only is it an eclectic mix of schools, but the bloggers themselves vary in status from holders of named chairs at elite institutions to those who are not even on the tenure track at their fourth tier schools. Some are even (gasp) legal writing teachers. We have folks who are noted experts in their fields, and other folks who are near-complete newcomers. Yet in an important sense, we are equal here-no one controls what we write. We are not vetted. We write, and we are judged on what we write.

While our primary target is law professors, we are actually read far beyond that circle. My own blog, ContractsProf, ${ }^{60}$ is regularly read by judges, lawyers, law students, and others looking for information about contract law. Dur- ing the semester we get 500 to 600 readers a day, small by Internet standards but huge compared to the ordinary audience for what law professors write. Many of our readers are not even in the U.S. We get quite a few from the countries of Eastern Europe and the former Soviet Union, not to mention common law jurisdictions like India, Malaysia, Singapore, Hong Kong, and Australia. And we are actually pikers at ContractsProf-some of the LawProf blogs have had a million or more visitors in less than two years. ${ }^{61}$ This is precisely the sort of thing a reformer would be expected to rejoice in-a real connection between law schools and the rest of the world.

If one is looking for is a direct ideological battle over the hearts of law schools, well, that is going on in the blogs, too. There are many law professor blogs with a clear ideological bent. The bloggers at the leftish Balkinization blog62 include faculty from Harvard, Princeton, George Washington, Georgetown, Maryland, Tulane, St. John's, even a partner with a big New York law firm. At the rightish Volokh Conspiracy, ${ }^{63}$ the authors are from UCLA, Northwestern, Duke, George Washington, Boston University, Temple, and George Mason, along with the head of a public interest advocacy group and a solo practitioner who does appellate work.

Both of these popular blogs have a comment feature that allows readers to engage directly with the writers with little moderating and few barriers. Some readers are supportive; some are hostile. Some make intelligent comments; others are idiots. The point is that these law 


\section{Franklin G. Snyder}

professors are, regardless of status, engaged with each other and with outsiders. They read each other's blogs and what their readers are saying about them. One of the most fascinating experiments on the web is the Becker-Posner Blog, ${ }^{64}$ where anybody with a keyboard can fawn over, sneer at, argue with, or correct two of the most influential current thinkers on law, Judge Richard Posner and Nobel laureate Gary Becker. Posner and Becker will even respond to the comments, at least to the saner ones.

All of this occurs outside the official channels of legal education. It is not comfortably under the thumb of the hierarchies. This obviously bothers some defenders of the old guard. Blogging is "a publishing medium with no vetting process, no review board, and no editor,"65 says one writer, who obviously thinks this is a very bad thing. "The author is the sole judge of what constitutes publishable material, and the medium allows for instantaneous distribution. ${ }^{66}$ The mere fact that a professor has a blogand thus has access to an audience outside the control of the institutions-is a potential danger to the powers that be:

The content of the blog may be less worrisome than the fact of the blog itself. Several [hiring] committee members [at the writer's school] expressed concern that a blogger who joined our staff might air departmental dirty laundry (real or imagined) on the cyber clothesline for the world to see. Past good behavior is no guarantee against future lapses of professional decorum. ${ }^{67}$

That danger has prompted some reactions from the defenders of the hierarchies. There is a widespread suspicion in the blogosphere that University of Chi- cago political science professor Daniel Drezner may have been denied tenure in large part because of his popular blog. ${ }^{68}$ Chicago Law School subsequently created its own blog under its own supervision, strictly for its own faculty members-though not, apparently, for the humble Bigelow Fellows who teach legal research and writing. ${ }^{69}$ Some experts even caution untenured faculty not to blog for fear it will undercut their chances for tenure. Academics, never known for their courage in the face of enemy fire, have taken the message to heart. "If any senior faculty had ever expressed disapproval about my blog," said one, "I would have stopped blogging immediately, as wimpy as that might sound." ${ }^{70}$ He explained that he would not want to jeopardize his job just to say what he really thought about things. ${ }^{71}$

However, these kinds of rear-guard actions are likely to fail. They have failed in the past. Once Protestant heretics discovered the printing press nothing the Catholic Church could do would put the genie back in the bottle. Once the colonial printing presses could operate free from Crown licensing, the way for revolution was paved. Any wholesale destruction of information controls spells serious trouble for existing hierarchies.

$$
* * *
$$

Does that mean that the hierarchies will go away? No. Will they get less insanely status-conscious and more egalitarian? It is hard to say. There are good reasons to believe they may get less status-conscious, as they grow more open to 


\section{NEXUS}

outsiders, but that does not mean they will become more egalitarian. Even without the near-total control of the dialogue that elite institutions have hitherto enjoyed, the elite institutions still have a powerful advantage: money. Recent experience outside academia suggests that when tight-knit old social hierarchies are undermined, they are not replaced by egalitarian institutions, but by market forces. These bring outsiders in, but they also increase the disparity between winners and losers. The passing of the old white-shoe law firm ethos, with its elite culture and lockstep compensation, has only increased the income disparities among and within law firms, even as it is opened the doors for outsiders to climb to the top of such firms. ${ }^{72}$ The decline of insider-dominated corporate boards and increased diversity on those boards resulted in more compensation for corporate CEOs, and a greater disparity between managers' and workers' pay. ${ }^{73}$ So it is entirely possible that in the brave new world of the 21st century, places like Harvard and Yale will simply buy up the people best at dominating the new order. That may even increase their dominance over the rest of legal education.

Or maybe not. The new technology might truly lead to a breaking down of caste. Those whose work rises to the top in this new world might have received their J.D.s from relatively humble schools. Elite institutions may find that a J.D. from them can no longer be counted on as a proxy for outstanding work-there may be good scholars who did not go to elite institutions. Similarly, scholars and teachers who are products of the elite institutions may come to realize that today they can do the kind of cutting-edge work they want at law schools almost anywhere in the country. They do not need to be in Cambridge or New Haven or Palo Alto to be major players in the scholarly game. Institutions may come to realize that those at the bottom of their own internal hierarchies are often fully the equal of-and even superior to-their own tenured professors.

As I say, I do not know which of these will come about. As a pessimist, I am inclined to bet on the money. Them that has, usually gets. But I would not mind being wrong.

Where does $L E R H$ and its call fit into all this? For some reason I'm reminded of an old book by Hilaire Belloc, ${ }^{74}$ in which he is recounting the history of Christianity. The early years of the seventh century marked its near-absolute triumph as the new State religion. The Christian hierarchy, united to the Byzantine throne, held sway throughout the whole of the old Roman Empire. Here and there, in places like Alexandria, Antioch, and $\mathrm{Da}$ mascus, I imagine there were educated and sophisticated Byzantines who loathed the hierarchies. I can see them writing to each other and organizing little Gnostic study groups to keep alive their desire to overturn the whole mess, to "make trouble" for the hierarchs. They are, like Kennedy some fourteen centuries later, advocates of interstitial revolution, inwardly focused on their own institutions.

Meanwhile, out in a desert peninsula the Romans never found it worthwhile to 


\section{Franklin G. Snyder}

conquer, the Prophet Mohammed is having a vision of the Angel Gabriel.

\section{Notes}

1 http://www.lonoke.com (follow "Area Churches" hyperlink; then click on any of desired church hyperlinks) (last visited Apr. 11, 2006).

2 Arkansas Department of Economic Development Home Page, http://www.1800arkansas.com (follow "Reports and Publications" hyperlink; then follow "Major Employers by County" hyperlink; then follow the "Lonoke County" hyperlink) (last visited Apr. 11, 2006).

3 Id.

4 Duncan Kennedy, Legal Education and the Reproduction of Hierarchy: A Polemic Against The System (New York University Press Critical ed. 2004) (1983). (hereinafter LERH). All citations herein are to this edition. I will include the original page numbers of the facsimile edition in parentheses.

5 Lani Guinier is the Bennet Bosky Professor of Law, Harvard University.

6 Mark Tushnet is the Carmack Waterhouse Professor of Constitutional Law, Georgetown University.

7 See Scott Turow, One-L (Farrar Straus \& Giroux 1977).

8 Inside Dust Jacket to Duncan Kennedy, LeGal Education and the Reproduction of HierarChy: A Polemic Against the System (New York University Press Critical ed. 2004) (1983):

9 http://www.amazon.com (search “Duncan Kennedy's Legal Education and the Reproduction of Hierarchy"; then scroll down to "Editorial Reviews") (last visited Apr. 11, 2006).

10 As do Mark Tusnet, Lani Guinier, and Scott Turow, respectively, on the back of the dust jacket. Mark Tusnet, Lani Guinier, Scott Turow Dust Jacket to Duncan Kennedy, Legal Education and the Reproduction of Hierarchy: A Polemic Against The System (New York University Press Critical ed. 2004) (1983).

11 Neil Duxbury, Patterns of American JurisPRUDENCE 493 (Oxford University Press reprint 1997).

12 Duncan Kennedy, How the Law School Fails: A Polemic, 1 Yale Rev. L. \& Soc. Action 71, 80 (1970).

13 http://www.duncankennedy.net/biography. (His only period outside it was a year clerking for Justice Potter Stewart on the U.S. Supreme Court, and a couple of gigs visiting at other Boston law schools) (last visited Apr. 11, 2006).

14 For those too young to remember, what is now the 100-school "first tier" used to be made up of the "first" and "second" tiers.

15 ContractsProf Blog, http://awprofessors.type pad.com/contractsprof_blog (last visited Apr. 11, 2006).

16 See, e.g., Symposium: The Common Law of Contracts as a World Force in Two Ages of Revolution: A Conference Celebrating the 150th Anniversary of Hadley v. Baxendale. 11 TEx. WESLEyan L. REV. 225, 225 (2005).

17 Kennedy, supra note 4 , at 15 (i).

$18 \mathrm{Id}$. at 16 (ii).

$19 I d$.

$20 I d$ at 19 (3).

21 Kennedy, supra note 12 , at 80 .

22 I.e., Andover, Yale, and Harvard.

23 Kennedy, supra note 4, Introduction at 1-4.

24 For a history of Carmelas through the medium of interlocking short stories by a guy from my neighborhood, see Daniel Houston-Davila, MAlinche's ChILdRen (University Press of Mississippi 2003). For information on the other two barrios in Norwalk, Varrio Norwalk and One-Ways, see James Diego Vigil, Barrio Gangs: Street Life AND Identity in Southern California (University of Texas Press 1988). Vigil worked as a youth counselor in all three.

25 Kennedy, supra note 12.

26 The Paramount Refinery is still in operation. You can get details and see a nice picture of the areas at http://www.ppcla.com (follow the "Locations" hyperlink; then follow the "Paramount" hyperlink from the map provided) (last visited Apr. 11, 2006).

27 I certainly would have opened it if I could have, a point which I kept trying to make to the guy, but there was a time lock.

28 Paul Carrington, Reproducing the Right Sort of Hierarchy, Commentary to DUNCAN KENNEDY, LEgal Education and the Reproduction of HierarChies: A Polemic Against the System 145-47 (New York University Press Critical ed. 2004) (1983).

29 Angela Harris \& Donna Maeda, Power and Resistance in Contemporary Legal Education, Commentary to DUNCAN KENNEDY, LEGAL EdUCATION and the Reproduction of Hierarchies: A Polemic Against the System 168 (New York University Press Critical ed. 2004) (1983).

30 Kennedy, supra note 4 , at 16 (ii).

31 Kennedy, supra note 4, Introduction at 3.

$32 \mathrm{Id}$. at 5.

33 Id. Kennedy seems saddened by the fact that that good left-thinking students sometimes see 


\section{NEXUS}

their "solid contempt" for "the cultural and intellectual style of right-wing youth" evaporate in classroom discussions, when they discover that there is "absolutely no way" that they will "catch up" with the right-wingers. It's not clear why such students are so far behind those with economics backgrounds that they are intimidated. Nor is it clear why conservative women and econ jocks manage to resist the hierarchical power of the professor more than leftist students.

34 Apologies to Yale, but there it is.

35 Kennedy emphasizes that he means a "Marx" study group, not a "Marxist" study group. Kennedy, supra note 4, Afterword at 203.

36 Louis Menard, Radicalism for Yuppies, in THe Eighties: A Reader 254, 258-59 (Gilbert T. Sewall, ed. 1997). Menard is here talking about CLS-oriented faculty, but the same description applies pretty much across the board, particularly at the most elite institutions.

37 Nathanial Berman, Against the Wrong and the Dead: A Genealogy of Left/MPM, 22 CARDozo L. REv. 1005, 1008 (2002). The "no-hassle pass" is Kennedy's practice of allowing students who don't want to talk in class to pass when called on.

38 See Duncan Kennedy, Legal Education as Training for Hierarchy, in The Politics of LAw: A Progressive Critique 54 (David Kairys ed. 1982, 2nd ed. 1990, 3d ed. 1998). This first edition was published by The New Press, subsequently part of Pantheon Books, a part of the Random House Group (which published the second edition). The current third edition is by Basic Books, a division of the Perseus Books Group.

39 See Duncan Kennedy, Legal Education and the Reproduction of Hierarchy, 32 J. LEGAL Educ. 591 (1982).

40 Kennedy, supra note 4, Afterword at 209.

41 See Duncan Kennedy, A Critique of AdjudiCation: Fin De Siecle (Harvard University Press 1997).

42 Kennedy, supra note 4, Afterword at 209.

43 Janet Halley, Of Time and the Pedagogy of Critical Legal Studies, Commentary to DunCaN KENNEDY, LEGAL EDUCATION AND THE REPRODUCTION of Hierarchies: A Polemic Against the System 185, 185-86 (New York University Press Critical ed. 2004) (1983). Not that Halley actually compares Kennedy to the Puritans; her quite reasonable point is that in both cases we have to try to recreate a worldview that seems to have vanished.

44 Kennedy, supra note 4, Afterword at 210-11.

45 See Peter Goodrich, Duncan Kennedy as I Imagine Him: The Man, the Work, his Scholarship, and the Polity, 22 CARdozo L. REv. 971, 973 (2001).
$46 \mathrm{http}: / /$ duncankennedy.net (last visited Apr. 11, 2006).

47 Not that he puts much stock in hierarchical titles, of course.

$48 \mathrm{http} / /$ www.duncankennedy.net/biography

(last visited Apr. 11, 2006).

49 A Sixties reference, perhaps? Maybe Bob Dylan's A Hard Rain's A-Gonna Fall? Creedence Clearwater's Who'll Stop the Rain?

50 http://www.duncankennedy.net/bibliography (last visited Apr. 11, 2006).

51 Kennedy, supra note 4 , at 78 (62).

52 Perhaps this is because Kennedy doesn't want to get inundated with crank mail. But this seems unlikely, given that his e-mail address and telephone number are there on the Harvard Law web site.

53 Kennedy, supra note 4, Introduction at 7.

54 Id.

55 SALT, Society of American Law Teachers Home Page, http://www.saltlaw.org (last visited Apr. 11, 2006).

56 The Federalist Society Home Page, http:// www.fed-soc.org (last visited Apr. 11, 2006).

57 SSRN, Social Science Research Network Home Page, http://www.ssrn.com (last visited Apr. 11, 2006).

58 Id. (The SSRN eLibrary consists of two parts: an Abstract Database containing abstracts on over 114,700 scholarly working papers and forthcoming papers and an Electronic Paper Collection currently containing over 86,500 downloadable full text documents in Adobe Acrobat pdf format) (last visited Apr. 11, 2006).

59 Law Professors Blog Home Page, http://www. lawprofessorblogs.com (last visited Apr. 11, 2006).

60 ContractsProf Blog Home Page, http://law professors.typepad.com/contractsprof_blog (last visited Apr. 11, 2006).

61 See Sentencing Law \& Policy Blog, http://sentencing.typepad.com $(1,174,458$ visitors since June 28, 2004); Tax Prof Blog, http://taxprof.typepad.com $(1,359,179$ visitors since April 15, 2004) (last visited Apr. 11, 2006).

62 Balkinization, http://balkin.blogspot.com (last visited Apr. 11, 2006).

63 The Volokh Conspiracy, http://volokh.com (last visited Apr. 11, 2006).

64 The Becker-Posner Blog, http://www.beckerposner-blog.com (last visited Apr. 11, 2006).

65 Ivan Tribble, Bloggers Need Not Apply, Chron. Higher Ed. (July 8, 2005), available at http://chronicle.com.

66 Id.

67 Id. 


\section{Franklin G. Snyder}

68 Daniel W. Drezner, http://www.danieldrezner. com/blog (last visited Apr. 11, 2006).

69 The University of Chicago Law School Faculty Blog, http://uchicagolaw.typepad.com (last visited Apr. 11, 2006).

70 Scott Jaschik, Too Much Information, INSIDE Higher Ed. (October 11, 2005), available at http:// www.insidehighered.com/news/2005/10/11/bloggers (last visited Apr. 11, 2006) (quoting Jeremy Freese).

71 Id.

72 Just a few days ago, as these words were written, the partners at London's Clifford Chance voted to change its venerable lockstep compensation system, under which its highest paid partners got 2.5 times as much as its least-paid partners, in favor of a new system which, in the U.S. at least, will boost the ratio to $4: 1$. The firm did so after it saw its New York office lose much of its top talent to other firms. See Anthony Lin, Clifford Chance Partners Approve Reform of Lockstep Compensation System, N.Y.L.J., Dec. 19, 2005.

73 See Franklin G. Snyder, More Pieces of the CEO Compensation Puzzle, 28 DEL. J. CoRP. L. 129 (2003).

74 Hilatre Belloc, The Great Heresies (1938). 
